\title{
Peran Kelompok Usaha Emping Melinjo Dalam Meningkatkan Kesejahteraan Ekonomi Masyarakat (Studi Kasus Di Desa Tuk Kecamatan Kedawung Cirebon)
}

\author{
Ayus Ahmad Yusuf ${ }^{1}$, Eef Saefulloh' ${ }^{2}$ Fitriya $^{3}$ \\ IAIN Syekh Nurjati Cirebon \\ ${ }^{1}$ e-mail: ayusayusuf@yahoo.co.id \\ 2 e-mail: eefsae2003@ gmail.com \\ 3 e-mail: fitriyahasanah12@gmail.com
}

\begin{abstract}
ABSTRAK
Tujuan penelitian pengabdian ini adalah untuk mengetahui seberapa jauh peran Kelompok Usaha Emping Melinjo yang ada di Desa Tuk Kecamatan Cirebon yang merupakan salah satu kategori usaha kecil yang turut serta berperan penting dalam hal menciptaan lapangan pekerjaan untuk mengurangi angka pengangguran dan sudah ada sejak tahun 1980-an. Secara tradisi, masyarakat mewarisi keahlian memproduksi emping melinjo dari orang tua terdahulu. Sampai saat ini, ratusan orang masih mempertahankan tradisi tersebut, baik sebagai pelaku usaha maupun tenaga produksinya. Penelitian ini menggunakan metode kualitatif deskriptif, dan sumber data yang digunakan ialah data primer dan data sekunder. Penelitian ini menyimpulkan bahwa peran kelompok usaha emping melinjo dalam meningkatkan kesejahteraan ekonomi masyarakat yang berada di Desa Tuk Kecamatan Kedawung Cirebon: Mampu meningkatkan tingkat pendapatan ekonomi masyarakat, mengurangi pengangguran, dan membantu memenuhi kebutuhan seharihari. Pertumbuhan ekonomi masyarakat meningkat karena kestabilan pemasukan dan pengeluaran yang lancar.
\end{abstract}

Kata kunci: Kelompok Usaha, Emping Melinjo, Kesejahteraan Ekonomi Masyarakat

\begin{abstract}
The purpose of this dedication research is to find out how far the role of the Emping Melinjo Business Group in Tuk Village, Cirebon District, which is one of the categories of small businesses that play an essential role in creating jobs to reduce unemployment and has existed since the 1980s. Traditionally, people inherit expertise in producing emping melinjo from their parents. Until now, hundreds of people still maintain the tradition, both as entrepreneurs and their production staff. This study uses descriptive qualitative methods, and data sources used are primary data and secondary data. This study concludes that the role of the emping melinjo business group in improving the economic well-being of people in Tuk Village, Kedawung District, Cirebon: Able to increase the level of community financial income, reduce unemployment, and help meet daily needs. The economic growth of the community has increased due to the stability of income and smooth expenditure.
\end{abstract}

Keywords: Business Group, Emping Melinjo, Community Economic WelfareBusiness Group 


\section{PENDAHULUAN}

Pada era globalisasi ini membuka peluang sekaligus tantangan bagi pengusaha Indonesia termasuk usaha kecil, karena pada era ini daya saing produk sangat tinggi, live cycle product relative pendek mengikut trend pasar, dan kemampuan inovasi produk relatif cepat. Usaha kecil merupakan salah satu bagian penting dari perekonomian suatu negara ataupun daerah, tidak terkecuali di Indonesia (Kristiyanti, 2012). Adanya Kelompok usaha dapat dikatakan sebagai salah satu solusi dapat membantu pemerintah dalam menangani masalah perekonomian yaitu pengangguran. Melalui industri-industri rumahan ini, masyarakat setempat direkrut untuk dijadikan karyawan tanpa melihat status pendidikannya. Tentu hal ini sangat membantu masyarakat yang kesulitan mencari pekerjaan karena status pendidikannya.

Dengan tumbuhnya industri rumah tangga di pedesaan, maka hal itu dapat meningkatkan perekonomian desa. Tujuan bisnis pada dasarnya mencari keuntungan. Adapun bisnis rumahan selain mencari keuntungan, yaitu untuk mencapai kesinambungan usaha. Kesinambungan usaha yakni bagaimana usaha yang dijalankan dapat berlangsung secara turun temurun meskipun persaingan usaha semakin ketat. Begitupun dengan adanya kelompok usahaini diharapkan bisa mensejahterakan masyarakat setempat. Karena kesejahteraan masyarakat merupakan tujuan utama dari pembangunan (Suharto, 2006).

Tabel 1. Jumlah Industri Unggulan di Kabupaten Cirebon Tahun 2014 -2017

\begin{tabular}{llcccc}
\hline \multirow{2}{*}{ No } & \multicolumn{1}{c}{ Jenis Komoditi } & \multicolumn{4}{c}{ Unit Usaha } \\
\cline { 3 - 6 } & & $\mathbf{2 0 1 4}$ & $\mathbf{2 0 1 5}$ & $\mathbf{2 0 1 6}$ & $\mathbf{2 0 1 7}$ \\
\hline 1. & Meubeul/Kerajinan Rotan & 1.331 & 1.370 & 1.362 & 1.398 \\
2. & Meubeul Kayu & 1.245 & 1.252 & 1.253 & 1.255 \\
3. & Emping Melinjo & $\mathbf{1 3 2}$ & $\mathbf{1 5 8}$ & $\mathbf{1 6 6}$ & $\mathbf{1 6 6}$ \\
4. & Roti dan Makanan Ringan & 417 & 571 & 770 & 775 \\
5. & Batu Alam & 344 & 344 & 347 & 347 \\
6. & Sandal Karet & 20 & 21 & 22 & 22 \\
7. & Batik & 521 & 565 & 593 & 593 \\
8. & Konveksi & 595 & 610 & 625 & 626 \\
9. & Kerajinan Kulit Kerang & 8 & 8 & 8 & 8 \\
\hline
\end{tabular}

Sumber: Badan Pusat Statistik Kabupaten Cirebon, 2018

Berdasarkan data dari Dinas Perindustrian dan Perdagangan Kabupaten Cirebon yang diterbitkan dalam buku Badan Pusat Statistik Kabupaten Cirebon Emping Melinjo masuk pada kategori Industri Unggulan di Kabupaten Cirebon tahun 2014 - 2017. Diketahui bahwa Emping Melinjo merupakan jenis komoditi pertama dalam bidang industri makanan dan selalu 
mengalami peningkatan pada setiap tahunnya. Salah satu daerah di Kabupaten Cirebon yang telah lama turut mengembangkan komoditi emping melinjo adalah Desa Tuk yang berada di Kecamatan Kedawung, berikut rincian jenis usaha yang ada di Desa Tuk Kecamatan Kedawung Cirebon;

Tabel 2. Jenis Usaha di Desa Tuk Kecamatan Kedawung Cirebon Tahun 2018

\begin{tabular}{clc}
\hline No & \multicolumn{1}{c}{ Nama } & Jumlah \\
\hline 1. & Emping Melinjo & $\mathbf{2 7}$ \\
2. & Kacang Gawil & 1 \\
3. & Rempeyek & 2 \\
4. & Kerupuk & 2 \\
5. & Tempe & 1 \\
6. & Kripik Pisang & 2 \\
7. & Gapit & 1 \\
8. & Rangginang & 1 \\
\hline Sumber: & Badan Pusat Statistik Kabupaten Cirebon, 2018
\end{tabular}

Berdasarkan tabel 2 sedikitnya ada delapan macam jenis usaha makanan ringan yang berada di lingkungan Desa Tuk Kecamatan Kedawung Cirebon, dengan adanya usaha tersebut membuka lapangan pekerjaan bagi mereka yang belum mempunyai pekerjaan, karena usaha di atas merupakan usaha sehari-hari yang dilakukan di rumahan. Jenis usaha yang paling unggul adalah emping melinjo karena emping melinjo merupakan ciri khas dari Desa Tuk itu sendiri, agar tetap eksis mengikuti perkembangan modernisasi. Usaha melinjo tidak begitu rumit dilakukan, hanya saja butuh tenaga extra dalam mengelola emping mulai dari proses sangrai sampai dicetak menggunakan alu. (Lili, 2018). Jumlah tenaga kerja usaha emping melinjo di Desa Tuk kini telah mencapai 384 orang diantaranya 276 orang perempuan dan 108 orang laki-laki yang tergabung didalamnya.

Desa Tuk selama ini dikenal sebagai salah satu sentra industri kecil emping melinjo di Kecamatan Kedawung Cirebon. Secara tradisi, masyarakat mewarisi keahlian memproduksi emping melinjo dari orang tua mereka terdahulu. Sampai saat ini, ratusan orang masih mempertahankan tradisi tersebut, baik sebagai pelaku usaha (produsen) maupun tenaga produksinya. Emping melinjo adalah sejenis keripik yang dibuat dari biji melinjo yang sudah tua. Proses pembuatan emping melinjo tidaklah sulit dan dapat dilakukan dengan menggunakan alatalat yang sederhana. Berdasarkan uraian diatas, peneliti tertarik mengetahui bagaimana peran kelompok usaha emping melinjo di Desa Tuk Kecamatan Kedawung Cirebon. Tujuannya adalah 
untuk mengetahui dan memahami lebih mendalam tentang adanya kelompok usaha emping melinjo agar membantu perekonomian keluarga.

\section{BAHAN DAN METODE}

Penelitian ini menggunakan pendekatan kualitatif deskriptif. Penelitian kualitatif dalam (Ikbar, 2012) dicirikan sebagai penelitian yang menggunakan situasi alamiah, menganalisis data secara induktif yaitu proses menarik kesimpulan berdasarkan kondisi yang khusus untuk kemudian diperlakukan secara umum dan meluas (Riduwan, 2010). Proses analisis digunakan secara deskriptif, dan melakukan metode penjaring data melalui studi dokumen, studi pustaka dan melakukan kontak langsung ke lapangan penelitian, yaitu mengunjungi secara personal kepada orang-orang yang terlibat dalam penelitian, melakukan pendekatan-pendekatan dengan kondisi dan keadaan penelitian (Gunawan, 2016) dengan tujuan mendapatkan pemahaman yang rinci dan jelas terkait dengan fenomena yang terjadi pada sasaran penelitian.

\section{HASIL DAN PEMBAHASAN}

Kelompok usaha emping melinjo di Desa Tuk Kecamatan Kedawung Cirebon sudah ada sejak tahun 1980- an. Jumlah kelompok usaha emping melinjo terus mengalami peningkatan, yang termuda berdiri tahun 2006 dan yang paling sepuh berdiri tahun 1980. Saat ini telah terdapat 27 kelompok usaha emping melinjo di Desa Tuk Kecamatan Kedawung Cirebon dengan kepemilikan modal usaha yang berbeda-beda pada tiap pemilik usaha, berikut rinciannya:

Grafik 1. Data Modal Usaha Pemilik Usaha:

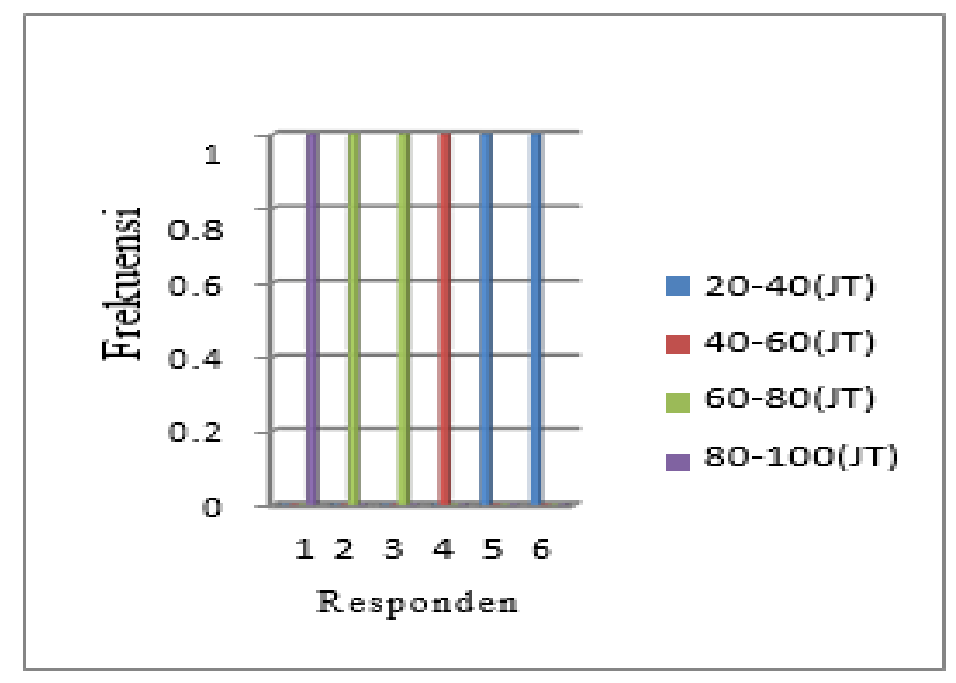

Sumber: Data Primer, 2018 
Modal merupakan poin penting dalam perputaran setiap usaha, baik usaha jasa maupun usaha non jasa. Dalam hal usaha emping melinjo, salah satu faktor yang menyebabkan eksisnya usaha emping melinjo sampai sekarang ini adalah karenakuatnya kepemilikan modal dalam menjalankan usaha emping melinjo di Desa Tuk Kecamatan Kedawung Cirebon. Berdasarkan grafik 1. diatas dapat diketahui Modal responden 1 atas nama Lili sebanyak Rp 100,000,000 , responden 2 atas nama Kadria sebanyak Rp 80,000,000, responden 3 atas nama Ahmad sebanyak Rp 65,000,000 responden 4 atas nama H. Jamali sebanyak Rp 50,000,000 , responden 5 atas nama Ratimah sebanyak Rp 35,000,000, responden 6 atas nama Hendra sebanyak Rp 20,000,000. Modal tersebut merupakan modal dimana mereka yang mengawali usaha sejak nol kembali setelah pelimpahan dari orang tuanya. Jadi mereka melanjutkan usaha yang sudah dibangun oleh keluarganya sejak dahulu. Dari kepemilikan modal tersebut, para pelaku usaha dapat menghasilkan omset perbulan sebagaimana grafik berikut;

Grafik 2. Data Omset Perbulan pemilik usaha:

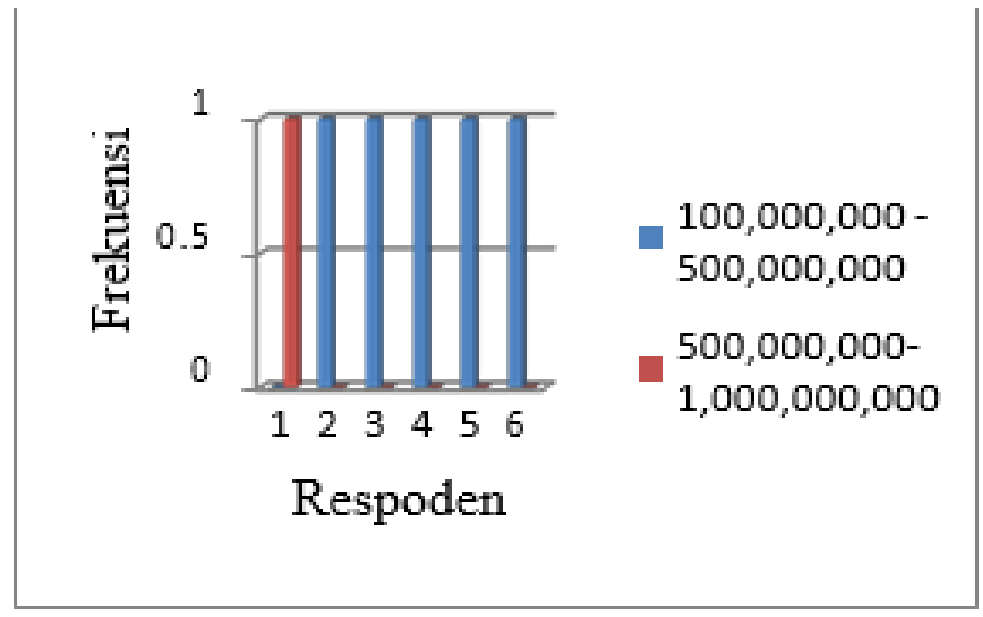

Sumber: Data Primer, 2018

Pada grafik 2. menjelaskan omset perbulan yang didapatkan oleh pengusaha emping melinjo di Desa Tuk Kecamatan Kedawung Cirebon. Dilihat dari banyaknya jumlah yang diproduksi setiap harinya maka perhitungan omset perbulan dapat disimpulkan seperti yang ada pada grafik tersebut. Total nilai yang ibu Lili dapatkan kisaran Rp 800,000,000/bulan sedangkan yang lainnya hanya kisaran $\operatorname{Rp~100,000,000~-~Rp~300,000,000/bulan.~Adapun~pengeluaran~perbulan~}$ untuk biaya sehari-hari pada responden 1 mengeluarkan biaya Rp 3,600,000, responden 2 mengeluarkan biaya $\operatorname{Rp~3,000,000,~responden~} 3$ mengeluarkan biaya Rp 3,300,000 untuk satu bulannya, responden 4 mengeluarkan biaya perbulannya $\operatorname{Rp} 3,400,000$, responden 5 mengeluarkan biaya perbulannya Rp 2,400,000, sedangkan responden 6 mengeluarkan biaya perbulannya $\operatorname{Rp} 2,600,000$. 


\section{Grafik 3. Aset kelompok usaha emping melinjo}

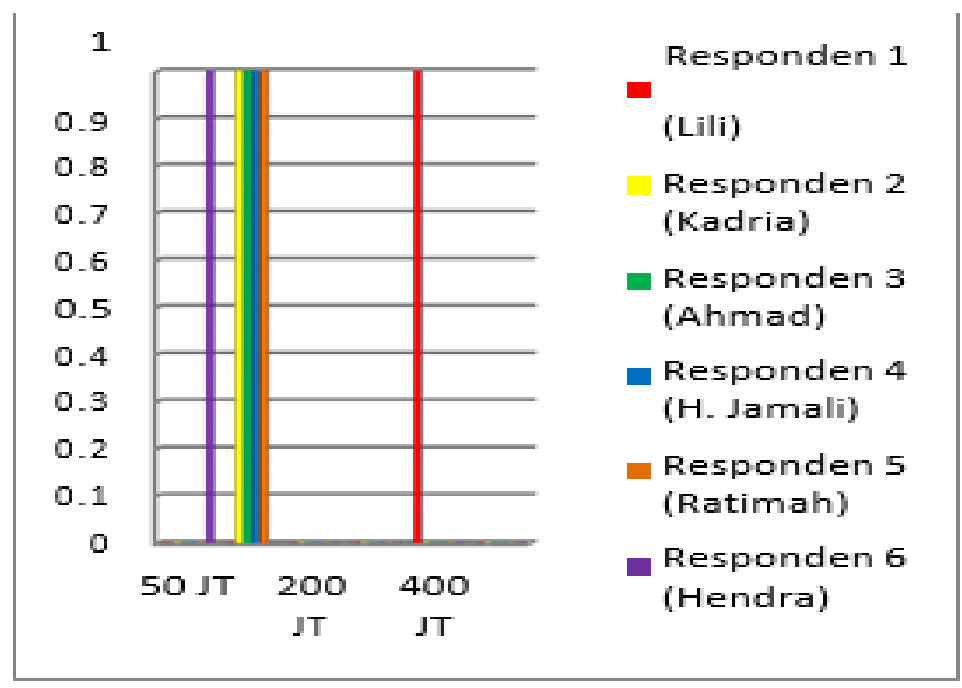

Sumber: Data Primer, 2018

Pada grafik 3. Diatas dapat diketahui pendapatan bersih perbulan yang diperoleh para pengusaha emping melinjo yang berada di Desa Tuk Kecamatan Kedawung Cirebon. Grafik sebelumnya menjelaskan tentang omset perbulan, hasilnya yang memiliki omset terbesar adalah usaha emping melinjo milik ibu Lili yang berskala besar. Penghasilan bersih perbulannyapun demikian, usaha emping melinjo milik Ibu Lili sudah mencapai angka Rp. 400,000,000 perbulannya. Bisa diprediksi bagaimana kehidupannya dapat dikatakan sejahtera taukah tidak. Kemudian responden yang lainnyapun berada pada pendapatan Rp 50,000,000 sampai dengan Rp. 100,000,00 perbulan. Hal tersebut yang kemudian menjadi salah satu alasan mengapa di Desa Tuk Kecamatan Kedawung mayoritas penduduknya adalah wirausaha. Dengan berwirausaha, tentunya dapat membuka peluang besar untuk lebih cepat sukses dibanding dengan profesi lainnya. Selain itu, mereka juga memiliki beberapa aset yang telah diperinci pada grafik berikut;

\section{Grafik 4. Aset kelompok usaha emping melinjo}

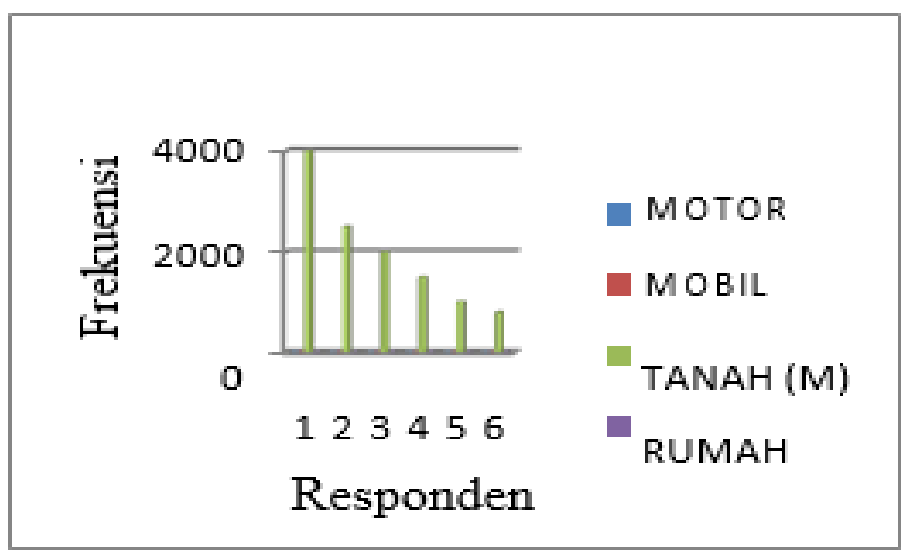

Sumber: Data Primer, 2018 
Dari grafik tersebut menunjukkan bahwa pelaku usaha mayoritas memiliki asset berskala sedang, seperti memiliki asset tanah, motor, mobil dan juga rumah. Namun juga diantaranya terdapat responden yang asetnya mencapai skala besar seperti memiliki 4 motor, 4 mobil, 4000 Meter Tanah, dan 3 unit rumah yang layak untuk ditempati. Dengan omset yang mereka dapatkan tersebut telah terbukti mampu menghidupi banyak orang yaitu para tenaga kerjanya dan keluarganya. Uang yang dihasilkan dari kegiatan usaha emping melinjo tersebut setidaknya dapat menghidupi keluarganya dengan layak. Mencukupi kebutuhan sehari- hari dan untuk kegiatan rutinitas harian yang lainnya ditambah dengan berbagai asset yang dimiliki juga oleh para pelaku kelompok usaha emping melinjo Desa Tuk Kecamatan Kedawung Kabupaten Cirebon.

\section{Grafik 5. Data Penghasilan Perbulan Tenaga Kerja:}

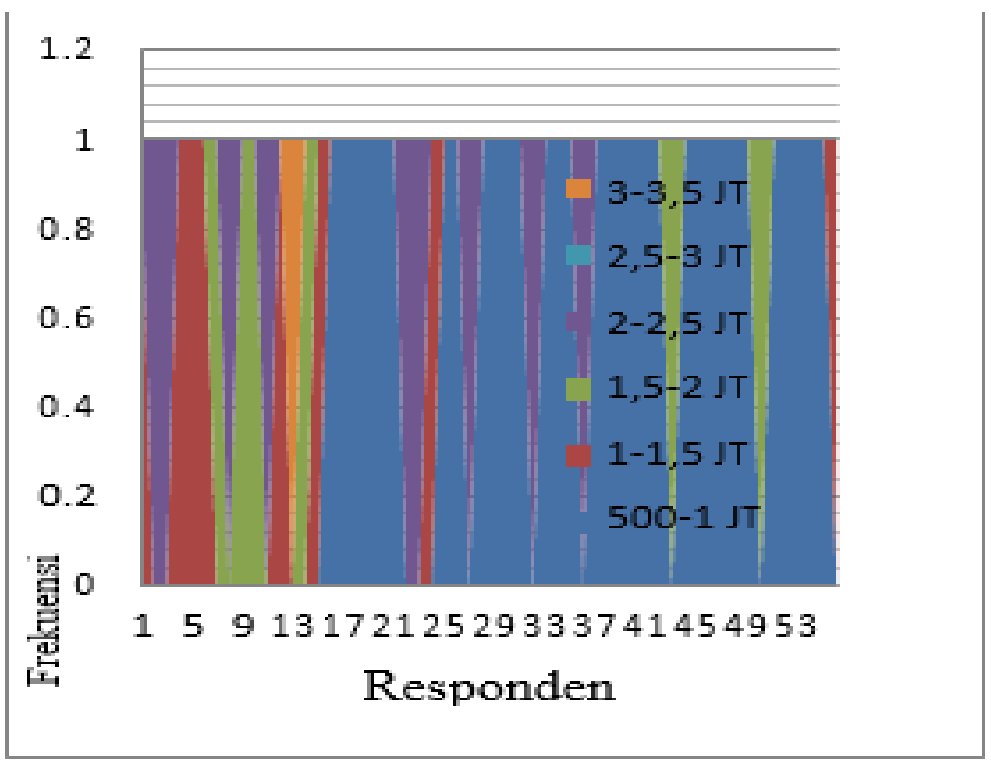

Sumber: Data Primer, 2018

Pada grafik 5. menjelaskan mengenai penghasilan perbulan para tenaga kerja emping melinjo. Dari grafik tersebut bahwa yang berpenghasilan diangka Rp 3,000,000 keatas ada satu orang, karena dia mendapatkan bagiannya lebih dari satu. Sedangkan yang mendapatkan penghasilan Rp 2,000,000 - 2,500,000 ada 9 orang merupakan bagian penggoreng, sedangkan yang berpenghasilan $\mathrm{Rp} \mathrm{1,500,000} \mathrm{-} \mathrm{2,000,000} \mathrm{merupakan} \mathrm{bagian} \mathrm{packing,} \mathrm{yang} \mathrm{berpenghasilan}$ $1,000,000$ - 1,500,000 ada 7 orang merupakan bagian penjemuran, dan yang berpenghasilan $\mathrm{Rp}$ 500,000 - 1,000,000 ada 32 orang merupakan bagian dari penggecek, karena upah penggecek masih rendah $1 \mathrm{~kg}$ melinjo dihargai dengan $\mathrm{Rp} 5.000$ maka dari itu penghasilannya masih rendah, tetapi dengan adanya uang insentif membuat para pekerja bertahan sampai dengan saat ini dan para tenaga kerja merasa nyaman dan betah. 
Dalam pelaksanaanya, pendapatan usaha emping melinjo juga mengalami peningkatan pada setiap tahunnya. Rata-rata para tenaga kerja di tahun pertama pendapatan upah perbulan naik sebesar Rp 200,000 sedangkan di tahun kedua pendapatan upah perbulan naik sebesar Rp 400,000 sedangkan di tahun ketiga pendapatan upah perbulan naik sebesar Rp 600,000 sedangkan di tahun keempat pendapatan upah perbulan naik sebesar Rp 800,000, di tahun kelima pendapatan upah perbulan naik sebesar Rp 1,000,000. Dengan kondisi tersebut para tenaga kerja merasakan sekali dampak perubahan ekonomi yang dirasakan setelah bekerja di usaha emping tersebut.

Sementara itu, keadaan masyarakat yang bekerja pada usaha emping melinjo dalam hal untuk pengeluaran perbulan rata-rata berada pada angka $\mathrm{Rp} 500,000$ - Rp 1,000,000 ada sebanyak 34 orang, perbulannya Rp 1,000,000 - Rp 1,500,000 ada sebanyak 7 orang, Rp 1,500,000 - Rp 2,000,000 ada sebanyak 10 orang, sedangkan yang pengeluarannya Rp 2,000,000 - Rp 2,500,000 ada sebanyak 1 orang. Perbedaan pengeluaran yang dikeluarkan berdasarkan tanggungan serta kebutuhan yang harus dipenuhi setiap bulannya.

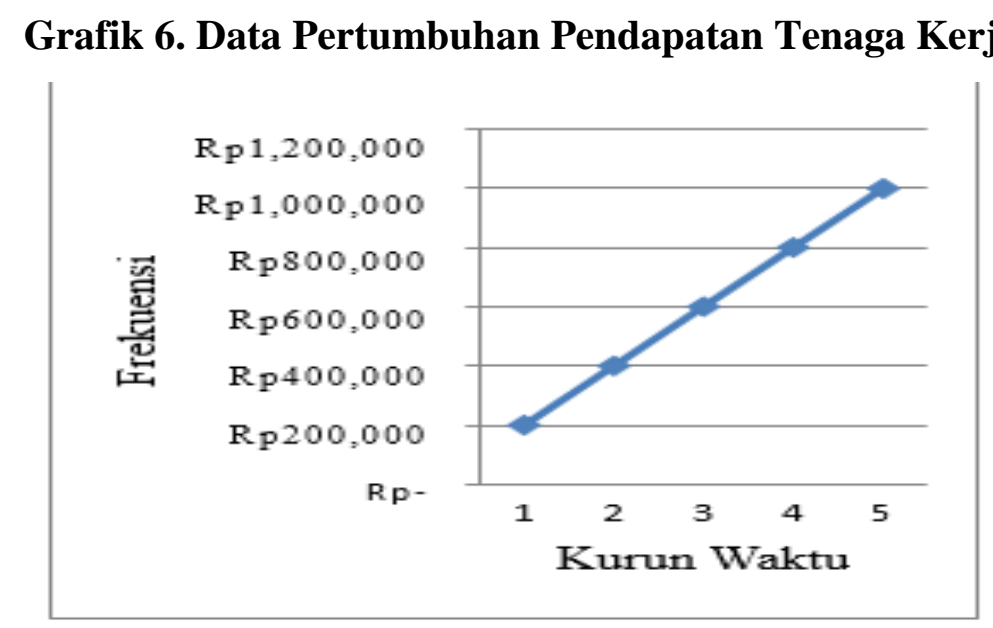

Sumber: Data Primer, 2018

Dari grafik 6. di atas dapat dilihat bahwa dengan mereka bekerja di usaha emping melinjo tersebut meningkatkan pendapatan mereka pada setiap tahunnya. Rata-rata para tenaga kerja di tahun pertama pendapatan upah perbulan naik sebesar Rp 200,000 sedangkan di tahun kedua pendapatan upah perbulan naik sebesar Rp 400,000 sedangkan di tahun ketiga pendapatan upah perbulan naik sebesar Rp 600,000 sedangkan di tahun keempat pendapatan upah perbulan naik sebesar Rp 800,000, di tahun kelima pendapatan upah perbulan naik sebesar Rp 1,000,000. Dengan kondisi tersebut para tenaga kerja merasakan sekali dampak perubahan ekonomi yang dirasakan setelah bekerja di usaha emping tersebut. 
Dari penjelasan tersebut menunjukkan bahwa tingkat kesejahteraan yang dialami para tenaga kerja meningkat karena peningkatan pendapatan mengakibatkan peningkatakan akan suatu kebutuhan mengalami kenaikan juga. Semakin tinggi tingkat pendapatan seseorang maka semakin tinggi tingkat kebutuhan akan suatu barang yang dibutuhkannya sehingga seimbang antara pendapatan dan pengeluarannya.

Grafik 7. Data Pertumbuhan Pangsa Pasar

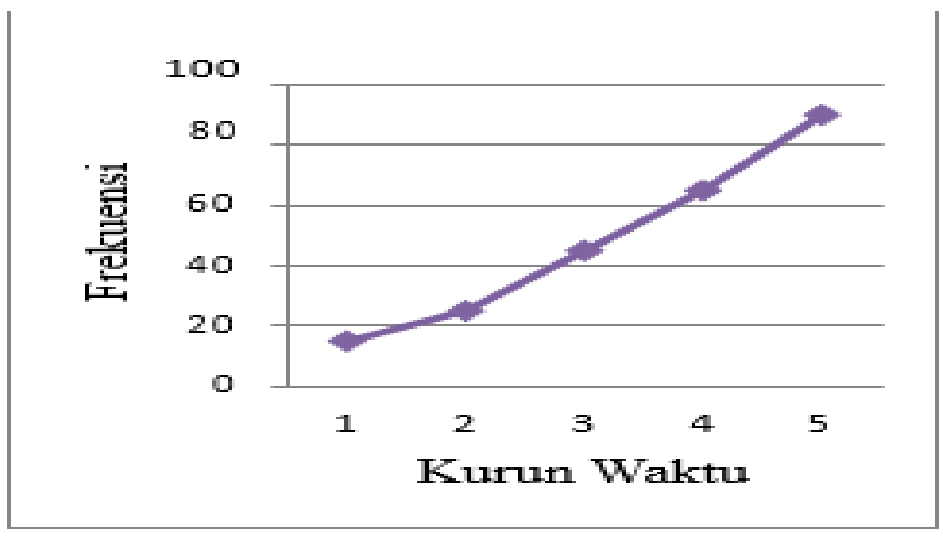

Sumber: Data Primer, 2018

Dari grafik 7. di atas dapat dilihat bahwa pertumbuhan dan perkembangan pangsa pasar didalam usaha emping melinjo mengalami kenaikan. Terhitung sejak tahun pertama tahun 2014 ada $15 \%$ perkembangan, tahun kedua tahun 2015 ada 25\% perkembangan, tahun ketiga tahun 2016 ada 45\% perkembangan, tahun keempat tahun 2017 ada $65 \%$ perkembangan, tahun kelima tahun 2018 ada $90 \%$ perkembangan. Dari data tersebut jelas bahwa pertumbuhan dan perkembangan pangsa pasar emping melinjo mengalami kenaikan setiap tahunnya.

\section{Grafik 8. Data Jumlah Perekrutan Tenaga Kerja}

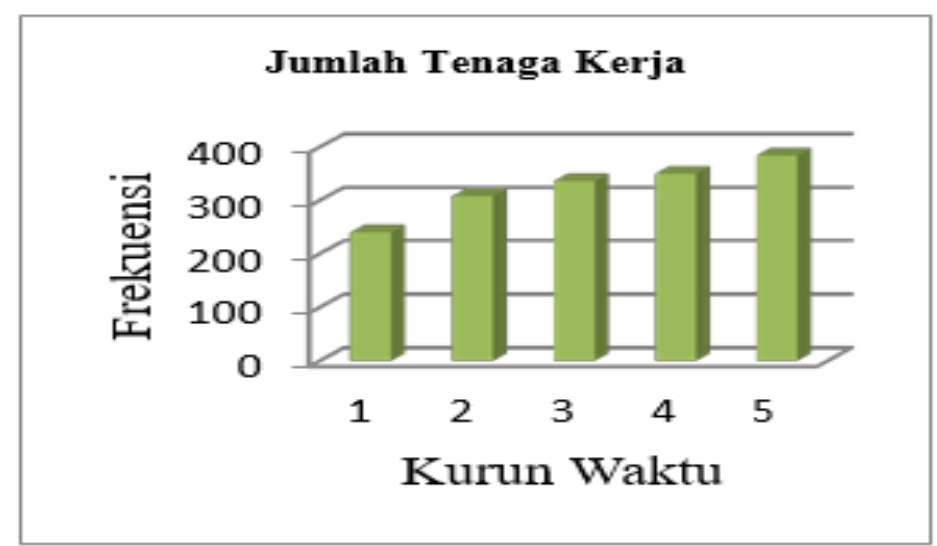

Sumber: Data Primer, 2018 
Dari grafik 8. di atas dapat dilihat bahwa jumlah perekrutan yang dilakukan oleh para pemilik usaha emping melinjo setiap tahunnya mengalami peningkatan. Pada tahun pertama terhitung tahun 2014 perekrutan tenaga kerja sebanyak 240 orang, tahun kedua terhitung pada tahun 2015 ada perekrutan tenaga kerja sebanyak 308 orang, tahun ketiga pada tahun 2016 ada perekrutan tenaga kerja sebanyak 336 orang, pada keempat tahun 2017 ada perekrutan tenaga kerja sebanyak 350 orang, dan pada tahun kelima tahun 2018 ada perekrutan tenaga kerja sebanyak 384 orang. Hal tersebut telah berdampak pada jumlah pengagguran yang ada di Desa Tuk Kecamatan Kedawung Kabupaten Cirebon, yang telah diperinci sebagaimana pada grafik berikut ini;

\section{Grafik 9. Data Jumlah Orang Pengangguran}

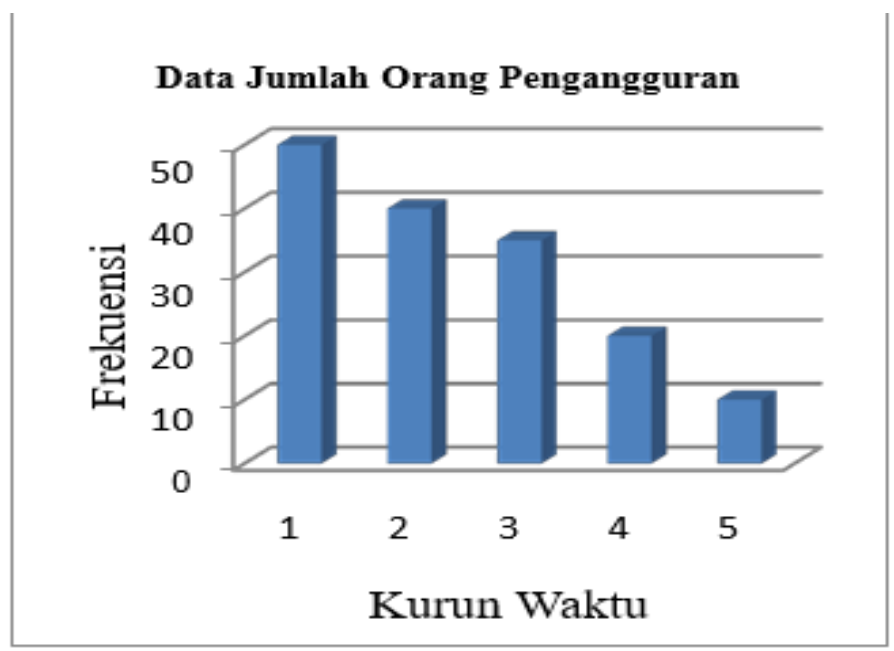

Sumber: Data Primer, 2018

Dari data grafik 9. di atas dapat dilihat bahwa angka pengangguran semakin menurun, dari tahun pertama tahun 2014 terhitung ada pengangguran berjumlah sebanyak 50 orang, di tahun kedua tahun 2015 ada sebanyak 40 orang, di tahun ketiga tahun 2016 sebanyak 35 orang, tahun ke empat tahun 2017 ada sebanyak 20 orang dan di tahun ke lima tahun 2018 ada sebanyak 10 orang. Data tersebut menunjukkan bahwa keberadaan usaha emping melinjo sangat membantu mengurangi angka pengangguran yang berada di Desa Tuk Kecamatan Kedawung Cirebon.

Berdasarkan penjelasan hasil temuan lapangan diatas, maka dapat diketahui bahwasanya kesejahteraan masyarakat Desa Tuk sudah sangat terbantukan oleh adanya kelompok usaha emping melinjo. Tingkat Kesejahteraan Ekonomi Masyarakat sudah cukup layak dan pantas dikatakan sejahtera karena bisa dikatakan sejahtera yaitu semua kebutuhan sandang, pangan, papan, kesehatan, keamanan, sarana prasarana memadai. Jadi sudah layak dikatakan sejahtera. Dalam hal ini sandang sudah seperti yang lain pada umumnya, papan pun sudah permanen semua 
tidak ada yang semi permanen, dan pelayanan masyarakat akan kesehatan dan keamanan sudah maksimal. Sedangkan kelembagaan yang dinaungi pemerintah desa pun berjalan sesuai tugasnya masing- masing.

Adanya usaha emping melinjo ini dapat membantu perekonomian masyarakat, bukan hanya tenaga kerjanya saja yang sejahtera akan tetapi pemilik usahapun sejahtera. Karena, usaha yang dibangunnya mengalami kemajuan sehingga taraf hidupnya makin lebih baik, bisa merekrut tenaga kerja lebih banyak lagi dan menjadikan Desa Tuk Kecamatan Kedawung Cirebon itu sebagai lokasi sentra perdagangan industri (panganan ringan) yang semakin berkembang dan dikenal masyarakat luas dengan segudang ciri khasnya yang tidak dimiliki daerah lain. Pendapatan yang meningkat bukan hanya berdampak pada perputaran uang saja, akan tetapi dengan berkembangnya usaha emping melinjo berdampak pada perekonomian masyarakat, pembangunan di sekitar tempat industri meningkat karena didukung oleh keadaan ekonomi yang rotasinya mendukung untuk melakukan kegiatan pembangunan tersebut. Perputaran uang semakin cepat, daya beli akan emping melinjo makin meningkat dengan kualitas barang yang terjaga mutu dan kualitas produknya membuat para konsumen sudah tidak ragu lagi jika mengkonsumsi produk emping melinjo yang dihasilkan oleh Desa Tuk Kecamatan Kedawung Cirebon.

Diluar dari hal itu, kelompok usaha di Desa Tuk Kecamatan Kedawung Cirebon juga masih sangat membutuhkan bantuan pemerintah guna untuk menopang usaha mereka agar terus berkembang, karena keinginan selaku pelaku kelompok usaha menginginkan emping melinjo itu bisa terkenal dan menjadi ciri khas dan oleh-oleh asli Cirebon agar Cirebon semakin terkenal dengan industri emping melinjonya. Agar Cirebon bukan hanya terkenal karena udangnya saja akan tetapi ada industri lain yang berperan didalamnya, karena semua ini berdampak pula kepada pertumbuhan ekonomi daerah.

\section{KESIMPULAN DAN SARAN}

Berdasarkan hasil analisis dan pembahasan penelitian yang sudah dipaparkan diatas dapat disimpulkan bahwa Peran Kelompok Usaha Emping Melinjo mampu menambah penciptaan lapangan pekerjaan, mampu meningkatkan pendapatan ekonomi keluarga, mampu meningkatkan kekayaan, mampu meningkatkan pertumbuhan dan perkembangan pangsa pasar, dan mampu meningkatkan pertumbuhan dan perkembangan transaksi tawar menawar. Dalam rangka menumbuhkan perekonomian desa, melancarkan perputaran uang dalam setiap waktunya, kemudian banyak masyarakat yang terkena dampak positif adanya kelompok usaha emping 
melinjo tersebut. Usaha emping melinjo tersebut sudah mampu memperbaharui ekonomi serta aspek lainnya di Desa Tuk Kecamatan Kedawung Cirebon. Jika tidak ada kelompok usaha emping melinjo di Desa Tuk Kecamatan Kedawung Cirebon akan banyak pengangguran dan keadaan Desa Tuk akan tertinggal oleh desa lain yang sudah berkembang dan memiliki pertumbuhan ekonomi yang stabil. Adapun saran untuk peningkatan kesejahteraan maupun pertumbuhan ekonomi dimasa mendatang, penulis merekomendasikan agar adanya bantuan dukungan baik moril maupun materiil dari pemerintah seperti halnya pengadaan koperasi sebagai wadah pemasaran dan perputaran siklus keuangan agar dapat dimanfaatkan sebagai pembiayaan kredit untuk masyarakat sekitar. Selain itu, perlu meningkatkan kreatifitas dan inovasi perkembangan produk kedepan agar dapat tetap bersaing dengan olahan komoditas yang sama maupun komoditas lainnya.

\section{UCAPAN TERIMA KASIH}

Kami mengucapkan banyak terimakasih kepada:

1. Seluruh Aparatur Pemerintah Desa Tuk Kecamatan Kedawung Kabupaten Cirebon

2. Para pemilik dan tenaga kerja yang tergabung dalam kelompok usaha pembuatan emping melinjo di Desa Tuk Kecamatan Kedawung Kabupaten Cirebon

\section{DAFTAR PUSTAKA}

BPS Kabupaten Cirebon. (2018). Kabupaten Cirebon dalam Angka. Kabupaten Cirebon.

Gunawan, I. (2016). Metode Penelitian Kualitatif Teori dan Praktik (Keempat). Jakarta: PT Bumi Aksara.

Ikbar, Y. (2012). Metode Penelitian Sosial Kualitatif Panduan Membuat Tugas Akhir/Karya Ilmiah (Pertama). Bandung: PT Refika Aditama.

Kristiyanti, M. (2012). Peran Strategis Usaha Kecil Menengah (UMK) Dalam Pembangunan Nasional. Jurnal Majalah Ilmiah Informatika, 3(1).

Riduwan. (2010). Belajar Mudah Penelitian. Bandung: Alfabeta.

Suharto, E. (2006). Membangun Masyarakat Memberdayakan Masyarakat. Bandung: PT Refika Aditama. 